\title{
Hogback Tombstones and the Anglo-Danish House
}

\author{
by JAMES WALTON
}

$\mathrm{I}$ N a number of publications W. G. Collingwood has described the north country hogbacks and he has suggested that they were replicas in stone of the dwellings prevailing at the time among the people responsible for their erection ${ }^{1}$. He was primarily concerned, however, with their development and dating, based upon the ornament employed. In this paper I have concentrated rather on the hogback as a representation of an Anglo-Danish house and its bearing on the origin of cruck construction.

The hogback is a recumbent tombstone in the form of a long, low house with a roofridge slightly arched lengthwise. Its ground plan (FIG. I, D) is bombé in shape, affording a plan which has only rarely been revealed by excavation. From Glendarragh, The Braaid, Isle of Man, Fleure and Dunlop have described two alignments which they consider represented the side walls of a boat-shaped house (FIG. I, A). These, they contend, were built of more durable materials to provide a stronger construction whilst the gable walls, which contained the entrances, were probably built of wattle. This is supported by the evidence of the hogbacks which show low stone ground-walls at the sides only and the walls at The Braaid are probably survivals of similar ground-walls. Fleure and Dunlop compare it to the 'banqueting hall ' of Hofstaoir, Mývatn, in northern Iceland, which is $\mathrm{I} I 8$ feet long and has incurved stone side walls varying from $19 \frac{1}{2}$ feet, at the ends, to 26 feet, in the middle, apart (FIG. I, B) ${ }^{2}$.

The finest examples of this plan so far discovered are the houses in the fortified Viking settlement of Trelleborg, near Slagelse in western Zealand, which date from a little before A.D. IO00 (FIGS. I, C and 2) ${ }^{3}$. These boat-shaped houses have been reconstructed by C. G. Schultz under the direction of the Danish National Museum. They have been given an arched roof carried on queen-post trusses and plank walls surrounded by a roofed gallery (FIG. 2) but this reconstruction, particularly as regards the nature of the roof-trusses, is open to some doubt. In deciding on the type of roof construction to employ, the architect drew upon models of houses having the same ground plan, notably the hogbacks of northern England and a casket from Kammin Cathedral in Pomerania. The Kammin casket (PLATE) is made of plates of elk horn held together by work of gilded bronze and from its ornamentation Norland concluded that it is probably Danish work of just the same period as Trelleborg. The ridge-tree and wall-plates extend beyond the gables and are terminated by carved animals' heads whilst the projecting ends of the principal rafters are shaped like birds' heads.

The roof-ridges of the hogbacks are almost invariably slightly arched and the roof itself is usually tegulated (FIG. 3). Whether the roof patterns represent tiles or shingles

${ }^{1}$ W. G. Collingwood, Northumbrian Crosses of the Pre-Norman Age, 1927. 'Anglo-Saxon Sculptured Stones ', Victoria History of the County of York, vol. II, 1912, pp. ro9-33.

I have accepted Collingwood's classification and chronology throughout this paper.

${ }^{2}$ H. J. Fleure and M. Dunlop, 'Glendarragh Circle and Alignments, The Braaid, Isle of Man', The Antiquaries Fournal, vol. xxII, 1942, pp. $5^{\mathrm{I}-2 .}$

${ }^{3}$ Poul Norlund, Trelleborg, I948, p. 28. 


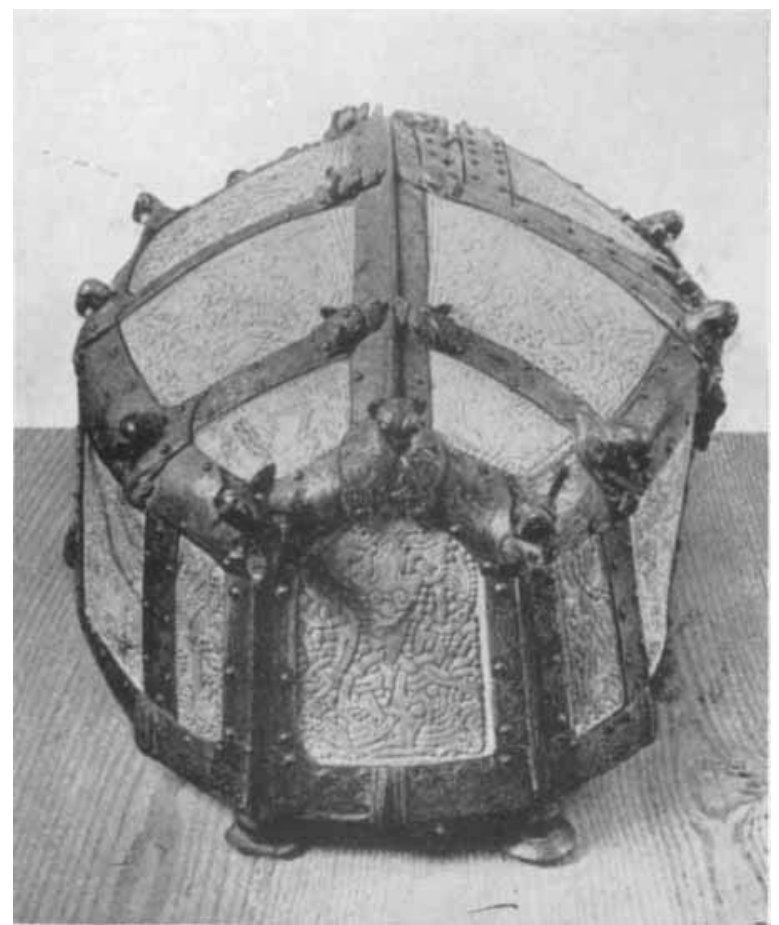

THE KAMMIN CASKLI

Ph. Danish National Museum, Copenhagen 


\section{HOGBACK TOMBSTONES AND THE ANGLO-DANISH HOUSE}

it is impossible to determine but in view of the origin of the hogbacks it is probable that they represent shingles such as were employed on Norwegian stave-churches. The use of shingles in Britain is of considerable antiquity. A manuscript illustration of about I 120 depicts a workman nailing shingles at a point below the lap ${ }^{4}$ but, as Innocent has pointed out, this may have been an error on the part of the draughtsman ${ }^{5}$. Alexander Neckam, writing in the I 2 th century, states that a hall may be roofed with straw, rushes, shingles or tiles and in 1260 King Henry III ordered that the thatch on the outer chamber

a.
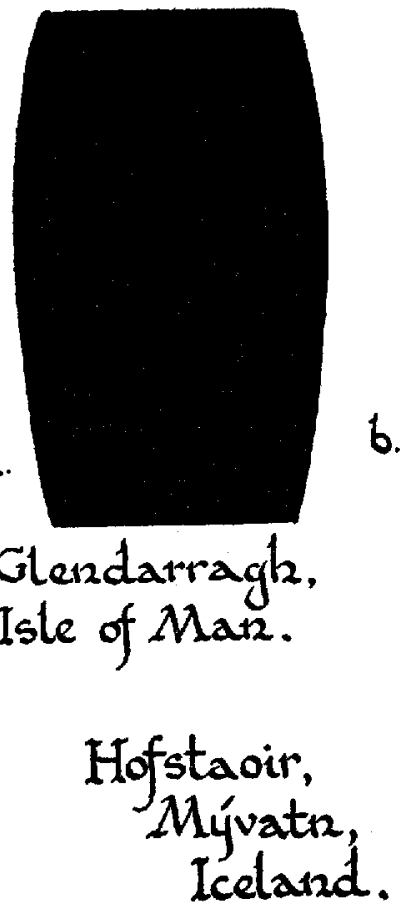

b.

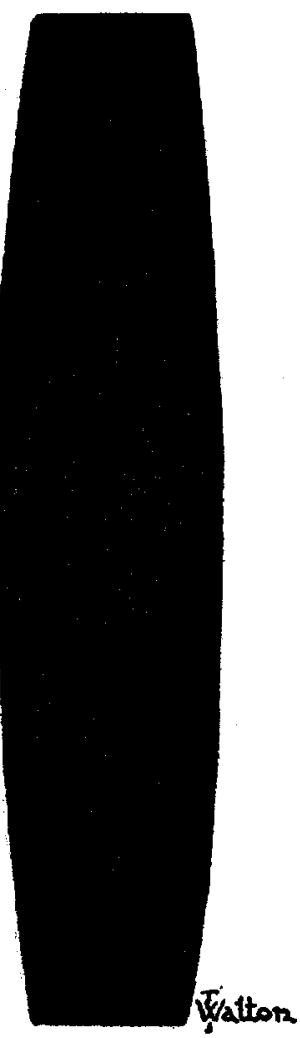

c.
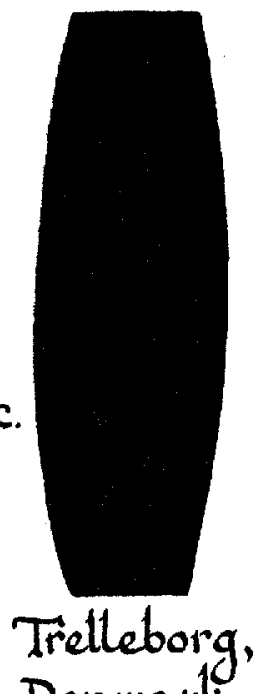
Dermatl.

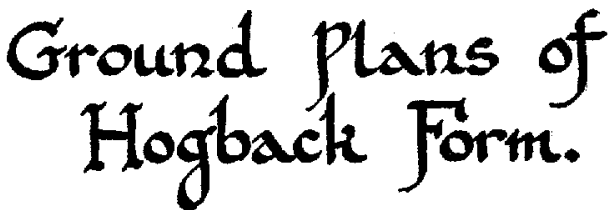

FIG. I

in the tower of Marlborough Castle should be replaced with shingles ${ }^{6}$. Even important buildings in the Middle Ages were so roofed and in 128I twelve oak trees were sent from Sherwood Forest to the Franciscan Friars of Lincoln for shingles ${ }^{7}$ whilst Salisbury Cathedral was similarly roofed from the Bramshaw woods in the New Forest. The

${ }^{4} \mathrm{~T} . \mathrm{H}$. Turner, Domestic Architecture in England from the Conquest to the end of the Thirteenth Century, $185^{1}$, facing p. 8.

${ }^{5}$ C. F. Innocent, The Development of English Building Construction, I9I6.

6 T. H. Turner, op. cit., p. 25 I.

${ }^{7}$ C. F. Innocent, op. cit., p. 184 . 


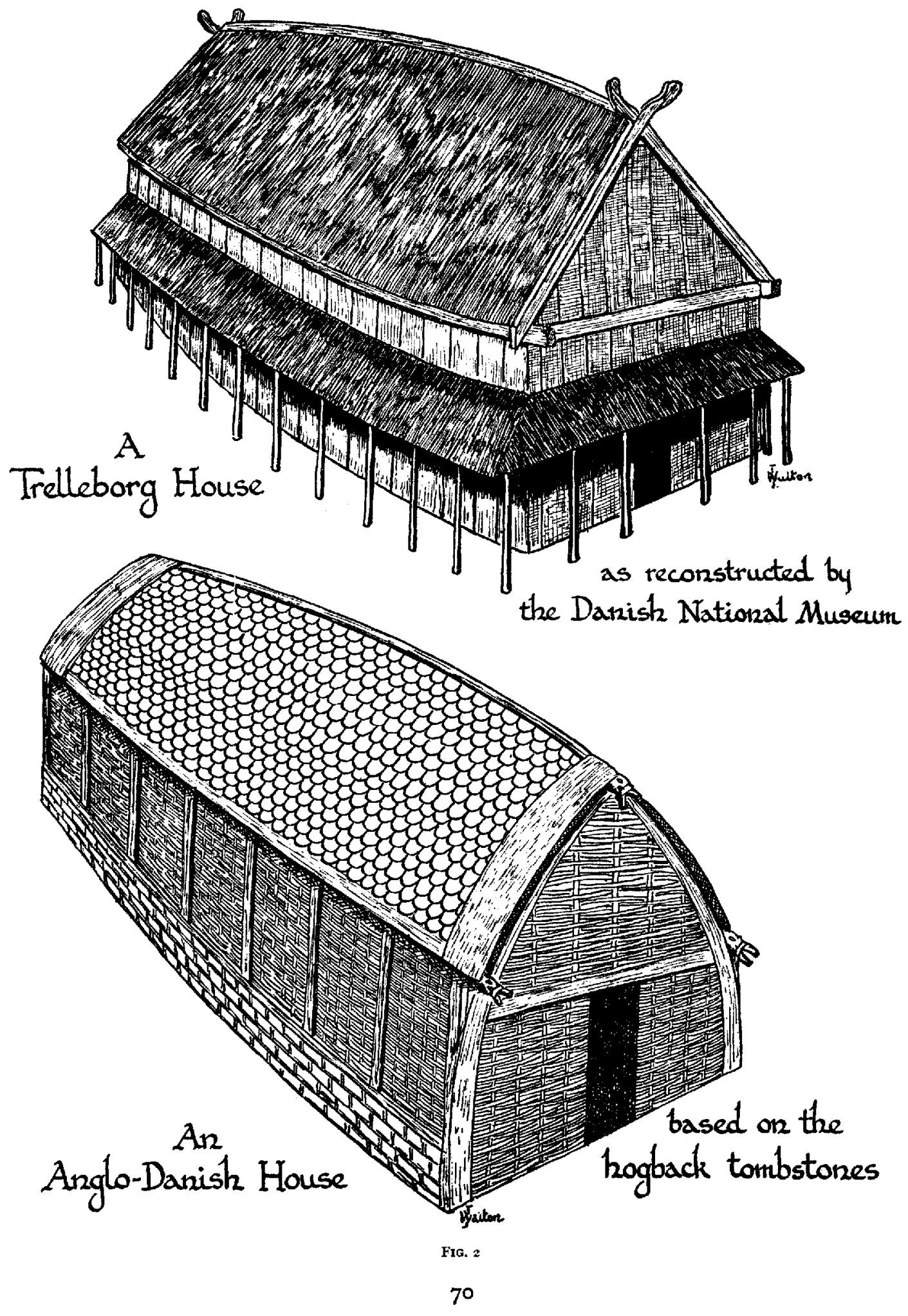



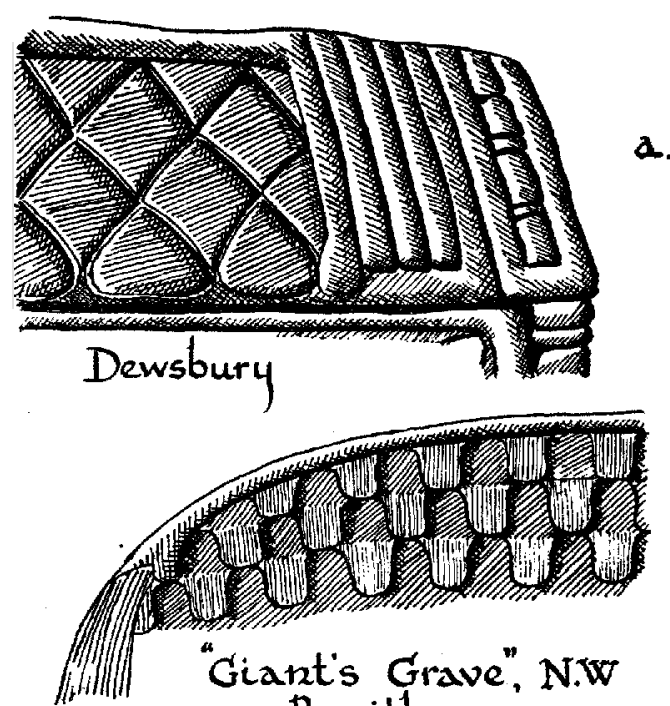
Penrith.
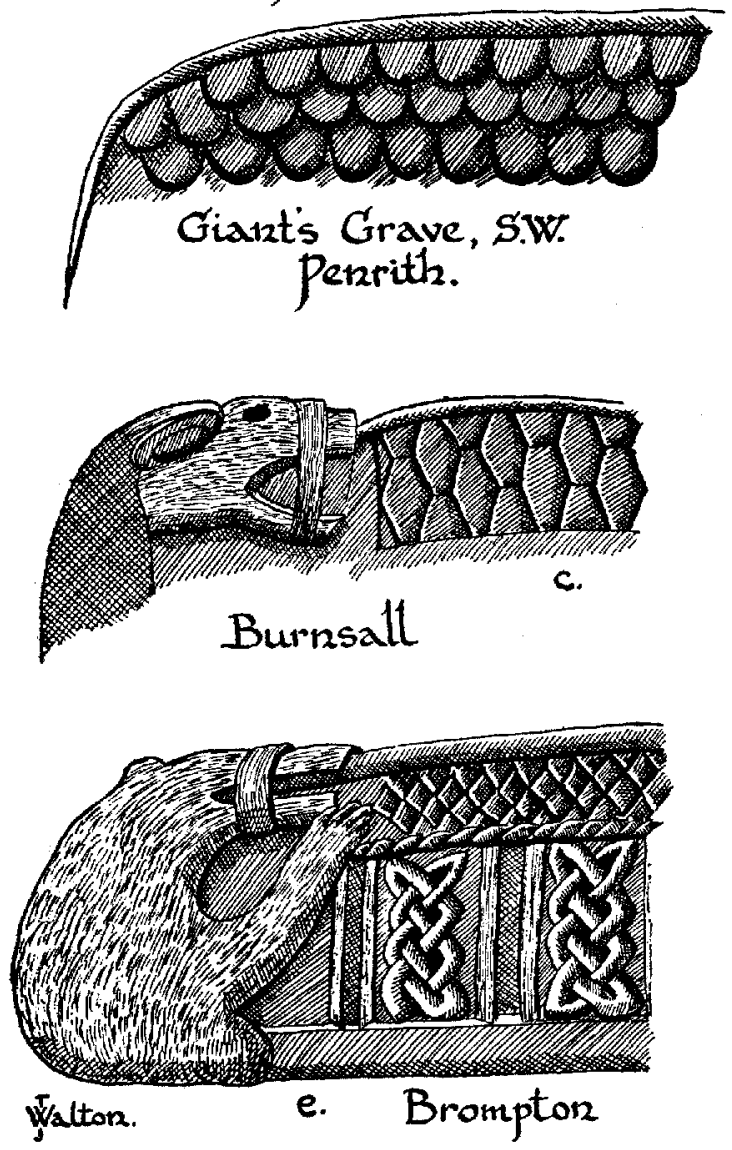

FIG. 3

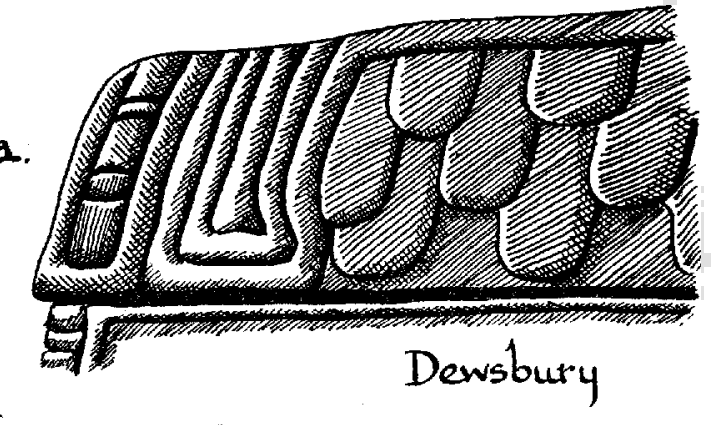

b.

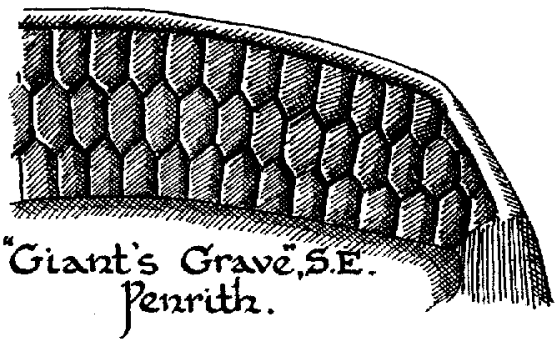

\section{Hogback Roof Details}
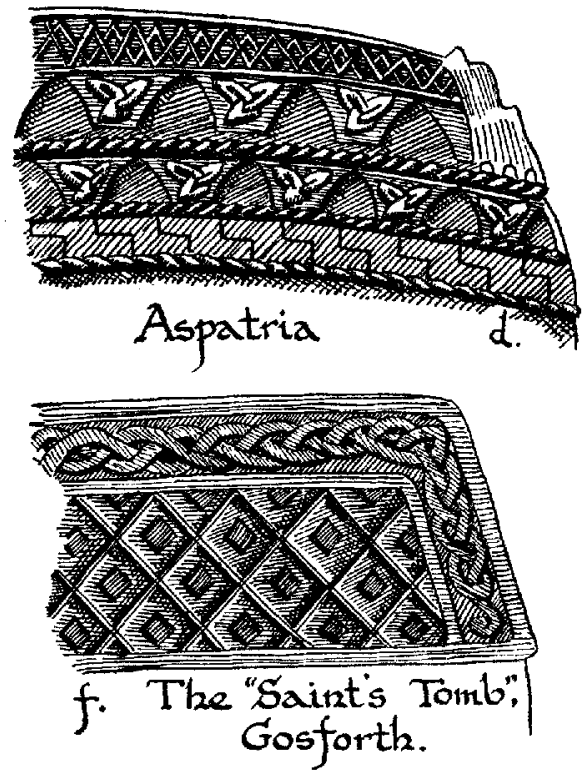


\section{ANTIQUITY}

Irish chief's house, as represented by the Temple at Jerusalem in The Book of Kells ${ }^{8}$, was also covered with ornate shingles, poetically described as 'birds' wings', which Ian Richmond suggests were painted in different colours like the hogbacks. ${ }^{9}$

Below the eaves the walls are most frequently decorated by an interlacing pattern, probably intended as a conventional representation of wattle walling. An example from Brompton, near Northallerton (FIG. 3, E), clearly depicts a low ground-wall with a wooden cill and a number of upright studs dividing the wall into panels filled with wattle, represented by the usual interlacing pattern. The late 9 th century hogback from Dewsbury, Yorkshire, shows what appear to be side walls of massive stone blocks (FIG. 4, A).

Towards the middle of the Ioth century the whole gable was taken up by a bear climbing onto the roof-ridge (FIG. 3, E). In some cases only the head is represented (FIG. 3, C) whilst at Easington the bear is replaced by a snake. Collingwood states that it was " very much in the taste of the Ioth century to put a head at the end of anything as a finial '10. A similar feature is depicted on the Kammin casket and on the Irish shrines and it undoubtedly represents a carved roof finial.

The picture of the Anglo-Danish house as represented by the hogback tombstones is that of a shingle-roofed building with a curved ridge-tree terminated by animalheaded finials. The side walls consisted of a low stone ground-wall and an upper structure of wide panels formed by a series of upright studs stretching from the cill to the wall-plate and filled with wattle. Although the wattle side walls rested on stone ground-walls the gables were entirely filled with wattle (FIG. 2). That the hogback is a stone replica of a timbered house is supported by Bede's statement that the sepulchre of St. Chad was a wooden monument made like a little house with a roof and a hole in the wall through which people used to put a hand and take some of the dust, valued as medicine.

Hogbacks were known in northern England prior to the Danish invasion, an excellent Anglian example of the late gth century being preserved in Dewsbury church (FIGs. 3, A and $4, \mathrm{~A}$ ). The gable of this hogback shows slightly sloping stone walls covered with a shingle roof but it also depicts what are probably a pair of crucks ; that is, curved timbers meeting at the apex to carry the ridge-tree ${ }^{11}$. From about A.D. 930 onwards the style of animal drawing changed, producing a type known as 'Jellinge' from the main region of its counterpart in Denmark. This group, represented by an example from Plumbland (FIG. 4, c), has a gable of undoubted cruck form and such a framework was usually represented until the end of the roth century.

The 'Warrior's 'Tomb' at Gosforth (FIG. 4, E), dated by Collingwood as $c$. A.D. I000 is of cruck type but the nearby 'Saint's Tomb', dated some fifty years later, has vertical side walls and an $\mathrm{I}$ th century example of late-Anglian pattern from Ingleby-Arncliffe has a definite king-post truss (FIG. 4, B). Midway through the I Ith century, therefore,

8 The Book of Kells (Trinity College, Dublin).

${ }^{8}$ Ian Richmond, 'The Irish Analogies for the Romano-British Barn Dwelling', The Journal of Roman Studies, vol. XxII, 1932, p. 98 .

${ }^{10}$ W. G. Collingwood, op. cit., 1927, p. 167.

${ }^{11}$ For descriptions of cruck construction see :-S. O. Addy, The Evolution of the English House, I9ro; C. F. Innocent, op. cit. ; James Walton, Homesteads of the Yorkshire Dales, 1947. ' Cruckframed Buildings in Yorkshire', Yorks. Arch. Fourn., 1948, pp. 49-66. 'The Development of the Cruck Framework', ANTiquity, I948, pp. 179-89; Cyril Fox and Lord Raglan, Monmouthshire Houses, Part 1, 195I; Iorwerth C. Peate, The Welsh House, $194^{\circ}$. 


\section{HOGBACK TOMBSTONES AND THE ANGLO-DANISH HOUSE}

the hogbacks indicate that there was a change in the construction of the Anglo-Danish house from cruck-truss to king-post truss.

An interesting sidelight on this change is afforded by the distribution of crucktrussed buildings in the Colne Valley region of West Yorkshire. Prior to 1069 this area was peopled by Angles and Danes, with an admixture of Norse, sufficiently united to rebel against William the Conqueror. In ro69 William's armies devastated large parts of the

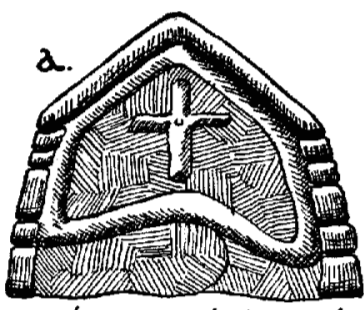

Dewsbury. Late 9th.cerat.

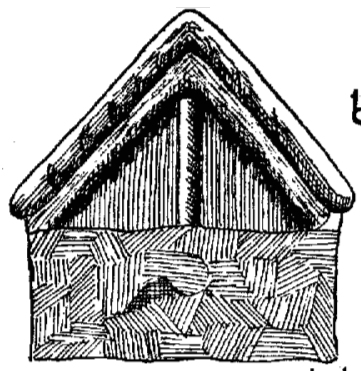

b.

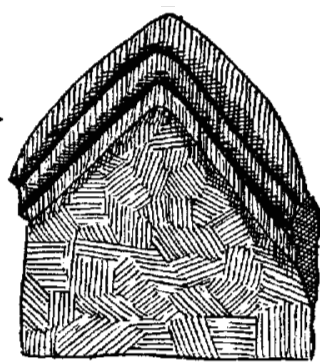

Ingleby-Arncliffe. 11tli.cent.

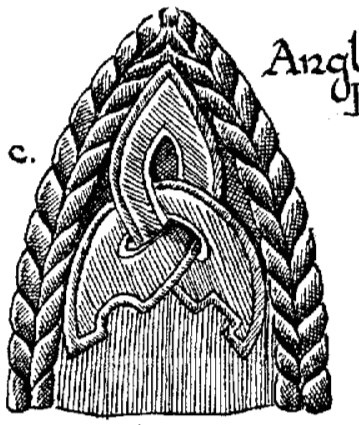

plumblard. c. 940

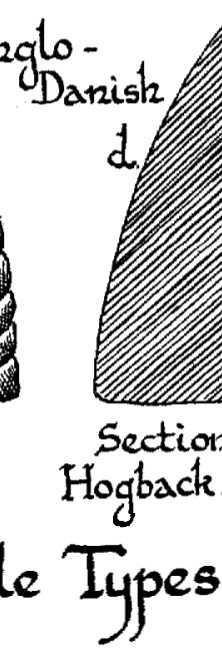

\section{Hogback Gable Types}
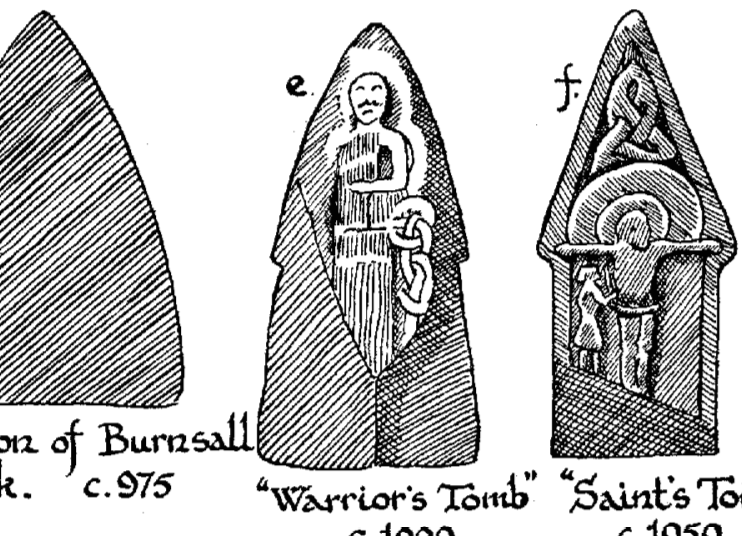

c. 1000 Gosforth

c.1050

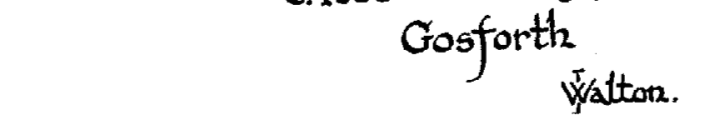

Fig. 4

Colne Valley as a reprisal for this rebellion leaving, however, certain parts unscathed. It is exactly in those parts that cruck construction has survived, notably a tiny pocket at Thorpe, near Almondbury. It would seem that prior to William's devastations the people of this district were living in cruck-trussed houses and that in those parts not laid waste they continued to do so after his armies had gone. The devastated parts remained unoccupied for at least the next seventeen years, ultimately to be re-peopled by Norse settlers from Lancashire and Westmorland ${ }^{12}$ who brought with them the king-post

12 W. G. Collingwood, 'Angles, Danes and Norse in the District of Huddersfield' (Tolson Memorial Musetum Handbook No. 2), 1929, p. 54. 


\section{ANTIQUITY}

method of house construction. This change in the Colne Valley occurred almost at the same time as that we have already noted in the form of the hogbacks.

As the Anglo-Danish hogbacks represent cruck-trussed timber dwellings it is probable that this method of building was introduced into Britain by the same peoples. It is unlikely that they would adopt a new method of house construction or accept one which already existed in Britain on their arrival in the new country. Still more unlikely is it that they would employ a new style for their tombstones. In fact such a change did not take place until the I Ith century. Historical records throw no light on the origin of cruck construction. The earliest dated English example is the Enstone tithe barn, which was built in $\mathrm{I}_{3} 82$, but there is a record of "two bent beams called " crokkes ", at Harlech in 1278 and Henblas, Llanderfel, Merioneth, is considered to be early 14 th century. All these, however, are developed structures.

The present-day distribution of cruck building in Europe affords a more definite clue as to its origin. Erixon has found evidences of cruck-like construction from Iron Age times in Denmark and Gotland and even from the Stone Age in Sweden and West Germany ${ }^{13}$. Stieren, Ottenjann and Lindner have briefly described true cruck constructions of primitive form still being employed in the German North Sea districts of Hümling, Oldenburg and Stade ${ }^{14}$ whilst van Giffen ${ }^{15}$ and Trefois have indicated its continuation along the coasts of Holland and Belgium where it has survived only in a modified form ${ }^{16}$.

In Britain Innocent's map marks the southern limit of cruck construction as a line drawn from the Wash to the Bristol Channel ${ }^{17}$ but this appears to be a generalization which has no foundation in fact. I cannot find a single record of any cruck-trussed building in Lincolnshire, nor in any part of eastern or south-eastern England. On the other hand cruck construction definitely extends into Hampshire and Dorset and, in a modified form, into Somerset and Devon (FIG. 5). I have no record of cruck building north of the Tees but there are frequent references to the use of the word 'sile' in Durham, Northumberland and Scotland and 'sile' is usually regarded as a north country equivalent of 'cruck'. This is not definitely proven, however, and it may equally well, from the contexts in which the word is used, refer to a normal roof couple. Roof trusses of cruck form have also been described from Caithness but these would appear to be a direct Scandinavian influence not connected with the true cruck of England and Wales.

The entire absence of cruck construction from eastern and south-eastern England has been explained by assuming that it was pushed into the north and west by other later methods. It is difficult to believe that not one single example, nor even a record of one, would not have survived and it seems much more probable that the people who introduced and followed the cruck method of building were never resident in eastern England.

13 Sigurd Erixon, 'Geschichte und heutige Aufgaben der Bauernhausforschung', in Funkenberg : Haus und Hof im nordischen Raum, II Band, I937.

${ }^{14}$ W. Lindner, Das niedersächsische Bauernhaus in Deutschland und Holland, 1912; A. Stieren, ' Eine germanische Siedlung in Westick bei Kamen, Kr. Unna, Westf., Diebisher ergrabenen Bauten der Siedlung', Westfalen, 1936.

${ }^{15}$ Verbal communication from van Giffen to A. Stieren.

${ }^{16} \mathrm{Cl}$. V. Trefois, in Folk, Zeitschrift des Internationalen Verbandes für Volksforschung, $\mathrm{I}$, Heft, 1937.

${ }^{17}$ C. F. Innocent, op. cit. 


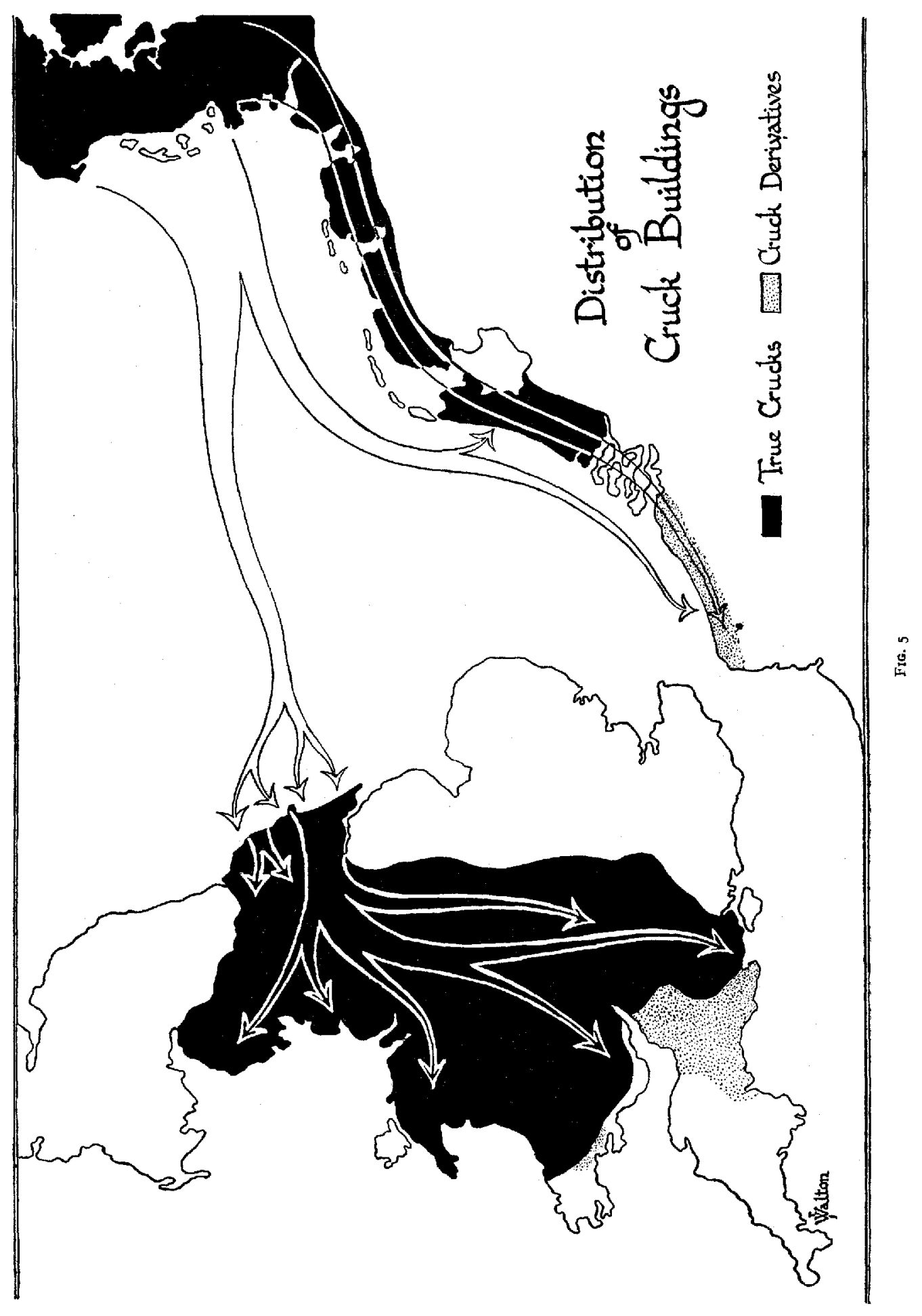




\section{ANTIQUITY}

The distribution of cruck buildings in Europe and Britain suggests an origin in the Schleswig region of southern Denmark and north Germany from where it travelled in one direction along the North Sea coast to Flanders and in another across the North Sea to the Yorkshire coast. Eventually it spread westwards to Cumberland and Westmorland and south-west as far as Hampshire and Dorset. The termination of each branch is marked by a modified cruck form due to contact with other methods and this modification is particularly marked in Devon and Somerset, in south-west Wales and in Flanders.

The available evidence afforded by the hogbacks and the known distribution of cruck construction in Europe indicates that originally the cruck method of house building was widely distributed throughout Denmark, south Sweden and north-west Germany but by the $5^{\text {th }}$ century it had generally been replaced by the paired-couple and king-post truss constructions. The cruck-truss only survived in certain localized areas, which could not have included Jutland, Angeln or Holstein otherwise cruck construction would have been found in the eastern parts of England which these peoples occupied. Its source of origin must, however, lie within the Anglian sphere of influence, as is proved by the Anglo-Danish hogbacks. The area which fulfils these conditions is that part of Schleswig north or east of Angeln. There in the 5 th century must have lived tribes who retained the cruck truss after it had been abandoned in adjoining areas but who had other cultural features in common with their neighbours. These tribes at the very beginning of the 6th century reached the Yorkshire coast, occupying the slopes around the edges of the Clevelands Hills, the North and South Wolds and the Vale of York, where they built their cruck-trussed dwellings. From there they spread westwards along the tributaries of the Ouse and south-westwards down the Trent valley. They continued to build crucktrussed dwellings until the middle of the I Ith century when they adopted the king-post truss but cruck construction has continued almost up to the present time in those areas which they culturally influenced.

I realize that to reach such a conclusion on the evidence of only two cultural features is open to error but Collingwood, from very different evidence, has concluded that the Anglian settlers of the Yorkshire coast came from the south of Denmark ${ }^{18}$. Other aspects of culture also confirm that there was no absolute uniformity throughout the Anglian group and, as Myres has pointed out, ' regional differences do exist between different parts' some of which ' reflect contemporary fashions in different parts of the continental homeland '19. There is, therefore, no reason why the Anglian or AngloDanish settlers of the north and west should not have retained a type of dwelling different from that of allied tribes in eastern England. Significant in this connection is the fact that the eastern boundary of cruck construction in England coincides with the western limit of the paired-couple roof construction which replaced the cruck-truss in SchleswigHolstein.

When I first suggested a possible Danish origin of the cruck truss ${ }^{20} \mathrm{Mrs}$ Piggott kindly drew my attention to a number of examples from Hampshire, Wiltshire and Dorset and pointed out that these would be difficult to correlate with a Danish sphere of influence. In his review of Ekwall's Concise Oxford Dictionary of English Place-Names Crawford referred to the origin of the place-name Thruxton, in Hampshire, which is identified as 'Thurkil's tun'. This personal name is Danish and Crawford pointed out

${ }^{18}$ W. G. Collingwood, op. cit., r 2929, p. 8.

${ }^{19}$ J. N. L. Myres, 'The Adventus Saxonum', Aspects of Archaeology in Britain and Beyond, I95I, pp. $235^{-6}$.

20 James Walton, op. cit., I948, p. 188. 


\section{HOGBACK TOMBSTONES AND THE ANGLO-DANISH HOUSE}

that " there is in the village a rectangular enclosure with a mound in one corner, of a type quite common within the Danelaw' and that 'it is reasonable to conclude that this was the actual $t u n$ of Thurkil '21. Thruxton is situated in the western part of Hampshire, in the region where cruck buildings occur, so that the existence of a cruck tradition beyond the normally accepted Anglian and Danish territories does not preclude an AngloDanish origin.

In preparing this paper I owe much to $\mathrm{Mr}$ N. Teulon Porter, Mr T. W. French, Sir Cyril Fox, Mr V. R. Webster, Mr O. G. S. Crawford and many others who have, over a number of years, kept me continually informed of any new records of cruck construction which they have found. It is on these records, together with my own, that I have based my map of cruck distribution in Britain. I am also particularly indebted to Herr Heinrich Koppold who has supplied me with records and literature of European cruck construction which has not previously been recognized by English students of folk building.

${ }^{21}$ O. G. S. Crawford, review of Eilert Ekwall : "The Concise Oxford Dictionary of English Place-Names', ANTiQuiTy, 1936, p. 493. 